\title{
Effect of Foliar Sprays on Seed Yield and Economics of Niger [Guizotia abyssinica (L.f.) Cass]
}

\author{
Bibhuti Bhusan Dalei ${ }^{1}$, Shyamal Kheroar ${ }^{1}$, Pavitra Mohan Mohapatra ${ }^{1}$, Somnath Panda $^{1} \&$ \\ Mohan Ramuji Deshmukh ${ }^{2}$ \\ ${ }^{1}$ Regional Research and Technology Transfer Station (OUAT), Semiliguda, Koraput, Odisha, India \\ ${ }^{2}$ Project Coordinating Unit, Sesame \& Niger, JNKV, Jabalpur, Madhya Pradesh, India \\ Correspondence: Shyamal Kheroar, Regional Research and Technology Transfer Station (OUAT), Semiliguda, \\ Koraput, Odisha-763002, India. Tel: 91-947-484-6416. E-mail: kheroarshyamal@gmail.com
}

Received: February 8, 2014 Accepted: April 3, $2014 \quad$ Online Published: May 15, 2014

doi:10.5539/jas.v6n6p143 URL: http://dx.doi.org/10.5539/jas.v6n6p143

\begin{abstract}
Field experiments were conducted on niger cv.GA.10 (Deomali) in red sandy to clay loam soils of RRTTS, Semiliguda, Koraput (Odisha) during kharif seasons of 2008, 2009 \& 2010 to find out suitable combination of soil and foliar application of nutrients (urea and di-ammonium phosphate) for maximizing growth and seed yield. Nine treatments consisting with different nutrient management were tested in randomized block design with three replications. The results revealed that, foliar applications of Urea and DAP gave better performance regarding growth and yield attributes. Highest seed yield (417.2 kg/ha), net monetary return (Rs. 4247.00/ha) and benefit-cost ratio (1.51), recorded with application of $100 \% \mathrm{RDF}+$ foliar application of $2 \%$ Urea twice at flowering and capitula formation stage $\left(\mathrm{T}_{4}\right)$ followed by $\mathrm{T}_{5}(\mathrm{RDF}+$ foliar spraying of $2 \%$ DAP twice at flowering and capitula formation stage) i.e. seed yield $387.7 \mathrm{~kg} /$ ha, net monetary return Rs. $3277.00 /$ ha and benefit-cost ratio 1.39 .
\end{abstract}

Keywords: niger, foliar application, DAP, Urea, seed yield, economics

\section{Introduction}

Niger [Guizotia abyssinica (L.f.) Cass] seeds contain a considerable quantity of edible oil (38 to 43\%), protein (20\%), sugar (12\%) and minerals essential for human and animal meals (Gentinet and Teklewold, 1995). India is the chief producer of niger seeds and ranks on the second and fourth position in the world for its acreage and annual production, respectively. Being a minor oilseed crop niger is most hardy and drought tolerant occupying a prominent place where moisture is the limiting factor and soils are sub-marginal to marginal in several parts of the country. Odisha has nearly 0.10 million hectare area under this crop with an annual production of 0.04 million tonnes and productivity of $357 \mathrm{~kg}$ seeds/ha (Damodaram \& Hegde, 2010). Among the oilseed crops, niger is considered to be a crop for resource poor farmers particularly in developing countries like India. It is generally grown with minimum agro inputs, nutrient stress is the most important factor responsible for its low productivity. Several workers have reported positive response of niger to foliar application of nutrients (Gautam, 2009). Nitrogen is susceptible to leaching losses; therefore, external application of nutrients becomes very important for enhancing the productivity of niger. Keeping this fact in view, the present investigation has been undertaken with the objectives to find out suitable combination of soil and foliar application of nutrients for better growth and yield of niger.

\section{Materials and Methods}

\subsection{Site Description}

Field experiments were conducted at research farm of Regional Research and Technology Transfer Station (OUAT), Semiliguda, Odisha, India, under Eastern Ghat High Land Zone $\left(18^{\circ} 42^{\prime} \mathrm{N}, 82^{\circ} 30^{\prime} \mathrm{E}\right.$, elevation $884 \mathrm{~m}$ above mean sea level) during kharif seasons of 2008, $2009 \& 2010$. The climate was hot and humid, with an annual mean rainfall $1567 \mathrm{~mm}$, most of which (90\%) was received during monsoon months (June to September). Mean summer and winter temperature were $34^{\circ} \mathrm{C}$ and $12^{\circ} \mathrm{C}$ respectively. 


\subsection{Experimental Soil}

The soil of experimental field was red and laterite with sandy to clay loam in texture. The $\mathrm{pH}$ of the soil was 5.8 with low in Organic carbon (0.03-0.05\%), available N (150-170 kg/ha), available P (16-18 kg/ha) \& available K $(152-160 \mathrm{~kg} / \mathrm{ha})$.

\subsection{Design of Experiment}

The experiment was arranged in randomized complete block design (RCBD) basing on three replications. The experiment having nine treatments consisting of different nutrient management, viz. $\mathrm{T}_{1}$ : Soil application of $100 \%$ recommended dose of fertilizer (RDF), $\mathrm{T}_{2}: \mathrm{T}_{1}+$ foliar application $2 \%$ Urea at flowering stage, $\mathrm{T}_{3}: \mathrm{T}_{1}+$ foliar application 2\% DAP at flowering stage, $\mathrm{T}_{4}: \mathrm{T}_{1}+$ foliar application $2 \%$ Urea at flowering and capitula formation stage, $\mathrm{T}_{5}: \mathrm{T}_{1}+$ foliar application $2 \% \mathrm{DAP}$ at flowering and capitula formation stage, $\mathrm{T}_{6}: 75 \% \mathrm{RDF}+$ foliar application $2 \%$ Urea at flowering stage, $\mathrm{T}_{7}: 75 \% \mathrm{RDF}+$ foliar application $2 \% \mathrm{DAP}$ at flowering stage, $\mathrm{T}_{8}: 75 \%$ $\mathrm{RDF}+$ foliar application $2 \%$ Urea at flowering and capitula formation stage and $\mathrm{T}_{9}: 75 \% \mathrm{RDF}+$ foliar application $2 \%$ DAP at flowering and capitula formation stage.

\subsection{Trial Management}

Niger cv. GA-10 (Deomali) was sown on 28th, 3rd and 14th August, 2008, 2009 and 2010 respectively with $10 \mathrm{~kg}$ seeds $/ \mathrm{ha}$ in $30 \mathrm{~cm}$ row to row and $10 \mathrm{~cm}$ plant to plant spacing, with a plot size $5 \mathrm{~m} \mathrm{x} 4.2 \mathrm{~m}$. The thinning \& weeding operations were done on 15 and 21 days after sowing (DAS) in every year. The recommended dose of fertilizer @ $\mathrm{N}_{40}+\mathrm{P}_{40}+\mathrm{K}_{20} \mathrm{~kg} /$ ha was applied to the crop. Full dose of $\mathrm{P}$ and $\mathrm{K}$ and half of $\mathrm{N}$ was applied through di-ammonium phosphate (DAP), muriate of potash (MOP) and urea respectively as basal. Remaining half of nitrogen was top dressed at 25 days old crop. Various observations viz. plant height, days to $50 \%$ flowering, number of branches/plant, number of capitulae/plant and numbers of seeds/capitula were recorded. The crop was harvested on 17th December, 21st November \& 13th December during 2008, 2009 and 2010 respectively. The seed yields were recorded after threshing of the harvested crop. The economic analyses viz. cost of production, net monetary return (NMR) and benefit-cost (B:C) ratio were made on the basis of market price.

\subsection{Statistical Analysis}

The data recorded on yield, growth and yield components were subjected to statistical analysis and treatment means were compared at $5 \%$ level of probability (K. A. Gomez \& A. A. Gomez, 1984).

\section{Results}

\subsection{Effect on Growth and Yield Attributes}

Effect of different nutrient management on plant height, days to $50 \%$ flowering, number of branches per plant, number of capitulae per plant and seeds per capitula are presented in Table 1. All the growth parameters achieved higher values for application of Urea or DAP along with the recommended fertilizer dose, but they were statistically non-significant. Highest plant height $(191.1 \mathrm{~cm})$, number of branches/plant (7.7), number of capitulae/plant (78.5) and seeds per capitula (30.6) were recorded with soil application of $100 \%$ RDF + foliar application of $2 \%$ urea at flowering \& capitula formation stage $\left(\mathrm{T}_{4}\right)$. Whereas, lowest plant height $(183.1 \mathrm{~cm})$ with $100 \% \mathrm{RDF}+$ foliar application of $2 \%$ DAP at flowering stage $\left(\mathrm{T}_{3}\right)$, number of branches/plant (6.7) and number of capitulae/plant (67.4) with $75 \% \mathrm{RDF}+$ foliar application of $2 \%$ Urea at flowering stage $\left(\mathrm{T}_{6}\right)$ and seeds per capitula (27.3) were recorded with 75\% RDF + foliar application of $2 \% \mathrm{DAP}$ at flowering stage respectively. Application of $100 \% \mathrm{RDF}\left(\mathrm{T}_{1}\right)$ required 61.9 days for $50 \%$ flowering, whereas, $75 \% \mathrm{RDF}+$ foliar application of $2 \% \mathrm{DAP}$ at flowering and capitula formation stage $\left(\mathrm{T}_{9}\right)$ took 63 days.

\subsection{Effect on Seed Yield}

The seed yields of crop are generally governed by various yield attributing characters. Consequence upon the superiority in yield attributes with the treatments receiving two foliar applications of $2 \%$ Urea at flowering and capitula formation stages in combination with $100 \% \mathrm{RDF}\left(\mathrm{T}_{4}\right)$ recorded highest seed yield $(417.2 \mathrm{~kg} / \mathrm{ha})$ followed by the $\mathrm{T}_{5}$ (two foliar applications of $2 \%$ DAP at flowering and capitula formation stages with $100 \%$ RDF) $387.7 \mathrm{~kg} / \mathrm{ha}$. There was $19.2 \%$ and $10.8 \%$ increase in seed yield due to foliar applications of $2 \%$ Urea and DAP twice at flowering and capitula formation stage in combination with RDF over soil application of $100 \%$ RDF $\left(\mathrm{T}_{1}\right)$. Lowest seed yield recorded with $75 \%$ RDF two foliar applications of $2 \%$ DAP at flowering and capitula formation stage $\left(\mathrm{T}_{9}\right)$. 
Table 1. Effect of soil and foliar applications of nutrient on growth and yield attributing characters of niger (Pooled data of 3 years)

\begin{tabular}{|c|c|c|c|c|c|}
\hline Treatments & $\begin{array}{l}\text { Plant height } \\
\quad(\mathrm{cm})\end{array}$ & $\begin{array}{l}\text { Days to } 50 \% \\
\text { flower } \\
\text { ing }\end{array}$ & $\begin{array}{c}\text { Branches/plant } \\
(\#)\end{array}$ & $\begin{array}{l}\text { Capitula/plant } \\
(\#)\end{array}$ & $\begin{array}{c}\text { Seeds/capitulate } \\
(\#)\end{array}$ \\
\hline $\begin{array}{l}T_{1} \text {. Soil application of } 100 \% \\
\text { RDF }\end{array}$ & 185.1 & 61.9 & 7.4 & 72.8 & 28.9 \\
\hline $\begin{array}{l}T_{2} . T_{1}+\text { foliar application } 2 \% \\
\text { Urea at flowering stage }\end{array}$ & 183.6 & 62.0 & 7.1 & 75.9 & 28.1 \\
\hline $\begin{array}{l}T_{3} . T_{1}+\text { foliar application } 2 \% \\
\text { DAP at flowering stage }\end{array}$ & 183.1 & 62.1 & 6.9 & 69.0 & 28.5 \\
\hline $\begin{array}{l}\mathrm{T}_{4} \cdot \mathrm{T}_{1}+\text { foliar application } 2 \% \\
\text { Urea at flowering and } \\
\text { capitula formation stage }\end{array}$ & 191.1 & 62.7 & 7.7 & 78.5 & 30.6 \\
\hline $\begin{array}{l}\mathrm{T}_{5} \cdot \mathrm{T}_{1}+\text { foliar application } 2 \% \\
\text { DAP at flowering and } \\
\text { capitula formation stage }\end{array}$ & 184.6 & 62.4 & 7.3 & 77.2 & 29.4 \\
\hline 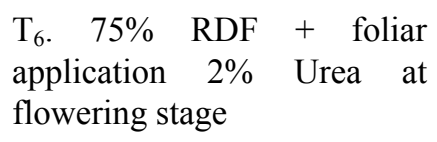 & 185.8 & 62.8 & 6.7 & 67.4 & 28.4 \\
\hline $\begin{array}{l}\mathrm{T}_{7} \quad 75 \% \quad \mathrm{RDF}+\text { foliar } \\
\text { application } 2 \% \text { DAP at } \\
\text { flowering stage }\end{array}$ & 184.0 & 62.7 & 7.2 & 72.9 & 27.3 \\
\hline $\begin{array}{lrr}\mathrm{T}_{8} .75 \% & \mathrm{RDF} & + \text { foliar } \\
\text { application } & 2 \% & \text { Urea at } \\
\text { flowering and } & \text { capitula } \\
\text { formation stage } & \end{array}$ & 183.7 & 62.8 & 7.0 & 73.5 & 29.0 \\
\hline $\begin{array}{lrl}\mathrm{T}_{9} .75 \% & \mathrm{RDF} & + \text { foliar } \\
\text { application } & 2 \% & \mathrm{DAP} \text { at } \\
\text { flowering and } & \text { capitula } \\
\text { formation stage } & \end{array}$ & 183.5 & 63.0 & 7.2 & 73.1 & 28.0 \\
\hline SE m $( \pm)$ & 4.73 & 0.43 & 0.34 & 4.81 & 1.40 \\
\hline $\mathrm{CD}(\mathrm{P}=0.05)$ & NS & NS & NS & NS & NS \\
\hline
\end{tabular}

$(\#)=$ Number.

Table 2. Effect of soil and foliar applications of nutrient on yield and economics of Niger (Pooled data of 3 years)

\begin{tabular}{|c|c|c|c|c|c|c|c|}
\hline \multirow[b]{2}{*}{ Treatment } & \multicolumn{4}{|c|}{ Seed yield (kg/ha) } & \multicolumn{3}{|c|}{ Economics } \\
\hline & 2008 & 2009 & 2010 & Mean & $\begin{array}{l}\text { Cost of } \\
\text { production } \\
\text { (Rs/ha) }\end{array}$ & $\begin{array}{l}\text { Net Monetary } \\
\text { Return } \\
\text { (Rs/ha) }\end{array}$ & $\begin{array}{l}\text { B:C } \\
\text { Ratio }\end{array}$ \\
\hline $\begin{array}{l}\mathrm{T}_{1} \text {. Soil application } 100 \% \\
\mathrm{RDF}\end{array}$ & 318.9 & 438.9 & 292.1 & 349.9 & 7940 & 2629 & 1.33 \\
\hline $\begin{array}{l}\mathrm{T}_{2} . \mathrm{T}_{1}+\text { foliar application } \\
2 \% \text { Urea at flowering stage }\end{array}$ & 331.1 & 469.8 & 307.1 & 369.4 & 8113 & 2967 & 1.36 \\
\hline $\begin{array}{l}\mathrm{T}_{3} . \mathrm{T}_{1}+\text { foliar application } \\
2 \% \text { DAP at flowering stage }\end{array}$ & 322.2 & 440.5 & 306.3 & 356.3 & 8163 & 2527 & 1.31 \\
\hline $\begin{array}{l}\mathrm{T}_{4} . \mathrm{T}_{1}+\text { foliar application } \\
2 \% \text { Urea at flowering and }\end{array}$ & 353.3 & 527.8 & 370.6 & 417.2 & 8270 & 4247 & 1.51 \\
\hline
\end{tabular}


capitula formation stage

$\mathrm{T}_{5} . \mathrm{T}_{1}+$ foliar application

$2 \%$ DAP at flowering and capitula formation stage

328.

483

350.8

387.7

8353

3277

$\mathrm{T}_{6} .75 \% \mathrm{RDF}+$ foliar application $2 \%$ Urea at flowering stage

$\mathrm{T}_{7} .75 \% \mathrm{RDF}+$ foliar application $2 \%$ DAP at flowering stage

$\mathrm{T}_{8} .75 \% \mathrm{RDF}+$ foliar application $2 \%$ Urea at flowering and capitula formation stage

T9. $75 \%$ RDF + foliar application $2 \%$ DAP at flowering and capitula formation stage

$\mathrm{SE} \mathrm{m}( \pm)$

$\mathrm{CD}(\mathrm{P}=0.05)$
230.0

400.8

$275.4 \quad 302.1$

7885

1177

270.0

7992

2185

242.

430.2

311.9

328.1

8075

1768

1.21
$260.0 \quad 410.3 \quad 290.5 \quad 320.3$

$431.0 \quad 316.7 \quad 339.2$

\section{Discussions}

\subsection{Effects on Growth and Yield Attributes}

Chemical fertilizer offers nutrients which are readily soluble in soil solution and thereby instantly available to plants. The increase in plant height, number of branches per plant in response to application of chemical fertilizers is probably due to enhanced availability of nutrients. The variation in plant height due to nutrient sources was considered to be due to variation in the availability of major nutrients. More number of branches and plant height might be due to the more availability of nitrogen, which plays a vital role in cell division. Several workers have reported marked superiority in growth parameters like plant height and branches/plant due to adequate nutrient supply in niger (Kachapur \& Radder, 1983 b; Trivedi et al., 1988; Gautam, 2009).

The productivity of niger plant is greatly dependent on the number of capitulate per plant and number of seeds per capitula. In present investigation maximum number of capitulate per plant and number of seeds per capitula were observed in the all the treated plants. Similar increase in these yield attributes have also been advocated by the several researchers (Paikray et al., 1990; Gautam, 2009).

\subsection{Effect on Seed Yield}

The increase in seed yield could be due to the increase in yield attributes (number of capitulate per plant and number of seeds per capitula) consequently. Niger required fully dry spell during flowering and seed setting, rainfall at flowering and seed setting period is very much detrimental for the crop yield, due to this reason yield variations were found among the experimental years. The increase in yield components can be due to the fact that available more water enhanced nutrient availability which improved nitrogen and other macro and micro elements absorption as well as enhancing the production and translocation of the dry matter content from source to sink. The superiority in seed yield due to foliar applications of fertilizers supplemented with $100 \%$ RDF mainly due to effect of additional quantity of $\mathrm{N}$ and $\mathrm{P}$ fertilizers as per needs by the crop. Several workers have emphasized for such improved nutrient use efficiency through the foliar applications of fertilizers in niger and other resembling crops under varying agro-climatic conditions (Reddy et al., 2005, Dixit \& Elamathi, 2007; Gautam, 2009; Anon., 2009).

\subsection{Economic Analysis}

The inputs and outputs prices of commodities prevailed during each year of trial were considered for calculating cost of production, net monetary return and benefit-cost ratio (Table 2). Applications of $2 \%$ urea at flowering and capitula formation stages in combination with 100\% RDF $\left(\mathrm{T}_{4}\right)$ recorded highest NMR (Rs.4247.00/ha) and B:C ratio (1.51), followed by $\left(\mathrm{T}_{5}\right)$ applications of $\%$ DAP at flowering and capitulla formation stages with $100 \% \mathrm{RDF}$ (Rs.3277.00/ha and 1.39 respectively). The cost of production (Rs.7835.00/ha) was lowest in $75 \% \mathrm{RDF}+$ foliar 
application of $2 \%$ Urea at flowering stage $\left(\mathrm{T}_{6}\right)$ and highest (Rs.8353/ha) with two foliar applications of DAP at flowering and capitula formation stage $+100 \% \operatorname{RDF}\left(\mathrm{T}_{5}\right)$. Similar finding has also been reported in niger crop under varying agro-climatic conditions (Gautam, 2009; Anon, 2009).

\section{Conclusion}

Based on the results from the investigation it is concluded that additional two foliar applications of $2 \%$ urea at flowering and capitula formation stages in combination with recommended dose of fertilizer can give higher seed yield and monetary return.

\section{References}

Anonymous. (2009). AICRP (Sesame and Niger) Annual Progress Report. Project Coordinating Unit (S \& N), JNKVV Campus, Jabalpur (p. 238).

Damodaram, T., \& Hegde, D. M. (2010). Oilseeds Situation: A Statistical Compedium. Directorate of Oilseeds Research, Hyderabad, 486.

Dixit, P. M., \& Elamathi, S. (2007). Effect of foliar application of DAP, micronutrients and NAA on growth and yield of green gram (Vigna radiata L.). Legume Research, 30(4), 305-307.

Gautam, S. P. (2009). Effect of nutrient management on growth and yield of niger [Guizotia abyssinica (L.f.) Cass]. M.Sc.(Ag) Thesis submitted to JNKVV, Jabalpur.

Gentinet, A., \& Teklewold. (1995). An agronomic and seed quality evaluation of niger [Guizotia abyssinica (L.f.) Cass] germplasm in Ethiopia. Plant Breed., 144, 375-376.

Gomez, K. A., \& Gomez, A. A. (1984). Statistical procedure for agricultural research an international rice research institute book (2 ed.). John Wiley \& Sons.

Kachapur, M. D., \& Radder, G. D. (1983). Studies on growth analysis in niger [Guizotia abyssinica (L.f.) Cass]. Mysore J. Agric. Sci., 17, 225-229.

Paikray, R. K., Mishra, R. C., Sahu, P. K., \& Panda, B. S. (1990). Response of niger varieties to levels of fertility. Orissa Journal of Agriculture Research, 3(3-4), 188-191.

Reddy, M. M., Padmaja, B., Rao, L. J., \& Radhakrishna, K. V. (2005). Effect of foliar spray of urea on nitrogen uptake and yield of urdbean (Vigna mungo L.) under rainfed conditions. Indian Journal of Dryland Agricultural Research and Development, 20(2), 151-154.

Trivedi, S. J. (1988). Effect of different levels of nitrogen and phosphorus on growth, yield attributes and yield of niger [Guizotia abyssinica (L.f.) Cass]. M.Sc. (Ag) Thesis submitted to Gujarat Agricultural University, Ahmedabad, India.

\section{Copyrights}

Copyright for this article is retained by the author(s), with first publication rights granted to the journal.

This is an open-access article distributed under the terms and conditions of the Creative Commons Attribution license (http://creativecommons.org/licenses/by/3.0/). 